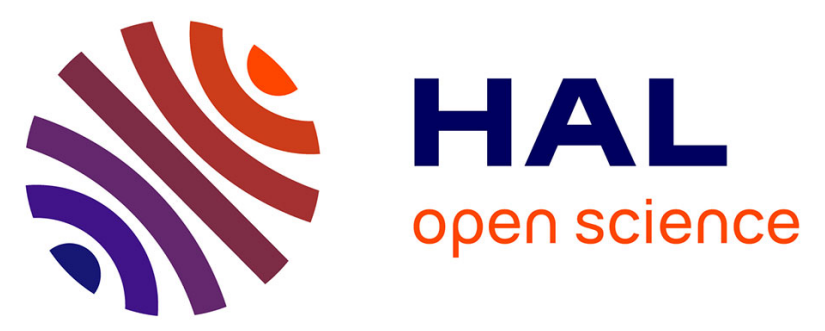

\title{
Molecular Mechanism of Action of 2-Ferrocenyl-1,1-diphenylbut-1-ene on HL-60 Leukemia Cells
}

\author{
Alane Cabral De Oliveira, Emanuella Gomes Da Silva, Danilo Damasceno \\ Rocha, Elisabeth A. Hillard, Pascal Pigeon, Gérard Jaouen, Felipe A. R. \\ Rodrigues, Fabiane C. De Abreu, Fabricia da Rocha Ferreira, Marilia O. F. \\ Goulart, et al.
}

\section{- To cite this version:}

Alane Cabral De Oliveira, Emanuella Gomes Da Silva, Danilo Damasceno Rocha, Elisabeth A. Hillard, Pascal Pigeon, et al.. Molecular Mechanism of Action of 2-Ferrocenyl-1,1-diphenylbut-1-ene on HL60 Leukemia Cells. ChemMedChem, 2014, 9 (11), pp.2580-2586. 10.1002/cmdc.201402219 . hal01230375

\section{HAL Id: hal-01230375 \\ https://hal.science/hal-01230375}

Submitted on 2 Jul 2020

HAL is a multi-disciplinary open access archive for the deposit and dissemination of scientific research documents, whether they are published or not. The documents may come from teaching and research institutions in France or abroad, or from public or private research centers.
L'archive ouverte pluridisciplinaire HAL, est destinée au dépôt et à la diffusion de documents scientifiques de niveau recherche, publiés ou non, émanant des établissements d'enseignement et de recherche français ou étrangers, des laboratoires publics ou privés. 


\section{Molecular Mechanism of Action of 2-Ferrocenyl-1,1- diphenylbut-1-ene on HL-60 Leukemia Cells}

Alane Cabral de Oliveira, ${ }^{[\mathrm{cc} \text { d] }}$ Emanuella Gomes da Silva,${ }^{[\mathrm{c}]}$ Danilo Damasceno Rocha, ${ }^{[\mathrm{e}]}$ Elizabeth A. Hillard, ${ }^{*[a]}$ Pascal Pigeon, ${ }^{[f, g]}$ Gérard Jaouen, ${ }^{[f, g]}$ Felipe A. R. Rodrigues, ${ }^{[\mathrm{e}]}$ Fabiane C. de Abreu, ${ }^{[\mathrm{c}]}$ Fabrícia da Rocha Ferreira, ${ }^{[c]}$ Marilia O. F. Goulart, ${ }^{[c]}$ and Letícia V. Costa-Lotufo ${ }^{*[b]}$

Keywords: antitumor agents; apoptosis; bioelectrochemistry; ferrocenes; HL-60 cells

[a] Dr. E. A. Hillard, CRPP, UPR 8641, CNRS and Université Bordeaux 33600 Pessac (France) E-mail: hillard@crpp-bordeaux.cnrs.fr

[b] Prof. L. V. Costa-Lotufo, Departamento de Fisiologia e Farmacologia Universidade Federal do Ceará, Campus do Porangabussu, Fortaleza, CE, 60430-270 (Brazil) E-mail: costalotufo@gmail.com

[c] Dr. A. C. de Oliveira, E. G. da Silva, Prof. F. C. de Abreu, Dr. F. da Rocha Ferreira, Prof. M. O. F. Goulart, Instituto de Química e Biotecnologia, Universidade Federal de Alagoas Maceio, Al, 57072970 (Brazil)

[d] Dr. A. C. de Oliveira, Faculdade de Nutrição, Universidade Federal de Alagoas (Brazil)

[e] Dr. D. D. Rocha, F. A. R. Rodrigues, Departamento de Fisiologia e Farmacologia Universidade Federal do Ceará (Brazil)

[f] Dr. P. Pigeon, Prof. G. Jaouen Chimie ParisTech (Ecole Nationale Supérieure de Chimie de Paris) 11 rue Pierre et Marie Curie, 75231 Paris Cedex 05 (France)

[g] Dr. P. Pigeon, Prof. G. Jaouen, Sorbonne Universités, Université Paris 6, Institut Parisien de Chimie Moléculaire (IPCM)-UMR 8232, 4 place Jussieu, 75252 Paris Cedex 05 (France)

The aim of this work was to investigate the mechanism of action of 2-ferrocenyl-1,1diphenylbut-1-ene (1) on HL-60 human leukemia cells. While inactive against noncancerous cells, 1 provoked a concentration-dependent decrease in viable tumor cells, primarily via apoptosis, as evidenced by analysis of cell morphology, activation of caspases 3 and 7, 
increased DNA fragmentation, and externalization of phosphatidylserine. Necrosis was observed only at the highest tested concentration $(4 \mu \mathrm{M})$. Compound 1 interfered with the cell cycle, causing an accumulation of cells in the $G_{1} / G_{0}$ phase. Interaction of $\mathbf{1}$ with dsDNA and ssDNA was observed by differential pulse voltammetry and confirmed by hyperchromicity in the UV/Vis spectra of dsDNA, with an interaction constant of $2 \times 10^{4} \mathrm{M}^{-1}$. Both the organic analogue 1,1,2-triphenylbut-1-ene (2) and ferrocene were inactive against cancer and noncancer cell lines and did not react with DNA. These results reinforce the idea that the hybrid strategy of conjugating ferrocene to the structure of tamoxifen derivatives is advantageous in finding new substances with antineoplastic activity.

\section{Introduction}

Ferrocene $(\mathrm{Fc})$ is receiving considerable attention as a bioisostere in medicinal chemistry, as it can potentiate the biological activity of small molecules used in treatment against cancer ${ }^{[1]}$ and contagious and parasitic diseases, ${ }^{[2]}$ among others. ${ }^{[3]}$ The ferricenium cation is known to be moderately cytotoxic, ${ }^{[4]}$ and the combination of $\mathrm{Fc}$ with small molecules that target receptors or enzymes has been shown to be an advantageous strategy in experimental chemotherapy. ${ }^{[5]}$ A series of ferrocenyl compounds, based on the tamoxifen skeleton, show antiproliferative effects against a variety of cancer cell lines, including hormone-dependent and -independent breast carcinoma. ${ }^{[6]}$ Derivatives in which one or both of the geminal phenyl rings are functionalized with an oxidizable group have shown the best (nanomolar) activity, and reactive quinone or aminoquinone methide intermediates have been implicated in

antiproliferative effects. ${ }^{[6 f]}$ Lacking such a functional group, 2-ferrocenyl-1,1-diphenylbut-1ene (1), is only moderately active against breast cancer cells ${ }^{[7]}$ and thus has not been studied further in this context. However, we recently showed that $\mathbf{1}$ demonstrates $\mathrm{IC}_{50}$ values below 2 $\mu \mathrm{M}$ for SF-295 human glioblastoma, HCT-8 human colon cancer, and HL-60 acute promyelocytic leukemia cell lines after $72 \mathrm{~h} .{ }^{[8]}$ This cytotoxicity, coupled with low hemolytic activity, prompted this further study of $\mathbf{1}$. 

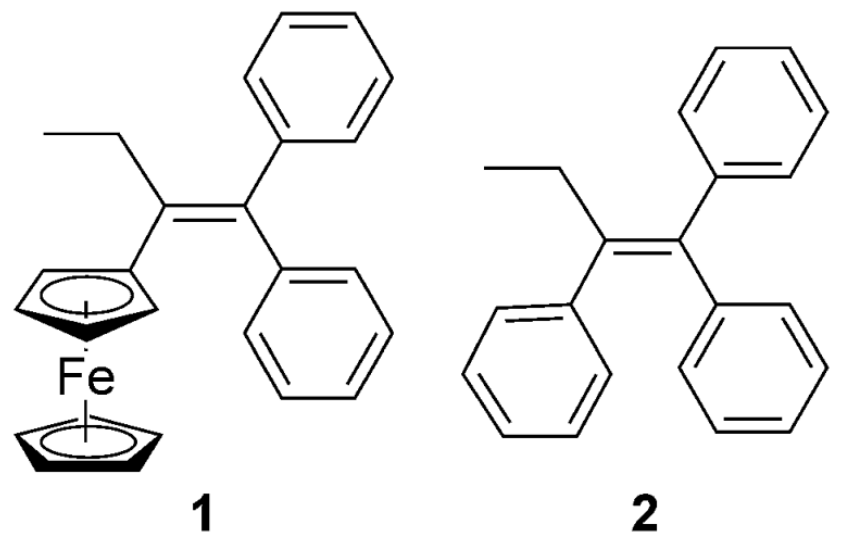

The present work is devoted to the investigation of the mechanism of biological action of $\mathbf{1}$ as a cytotoxic agent against HL-60 cells. The influence of $\mathbf{1}$ on cell morphology, cell membrane integrity, DNA fragmentation, cell cycle, phosphatidylserine (PS) externalization, and activation of caspases 3 and 7 was studied. The ability of 1 to interact with DNA was assessed through electrochemical and spectrophotometric experiments using double-stranded DNA (dsDNA)-modified electrodes and dsDNA and single-stranded DNA (ssDNA) in solution. To elucidate the role of the ferrocenyl group, the antiproliferative properties of the phenyl analogue, 1,1,2-triphenylbut-1-ene (2), were also evaluated.

\section{Results}

\section{Antiproliferative effects}

In the present study, we compared the antiproliferative properties of $\mathbf{1}$ with its organic analogue, 2, against cancerous and noncancerous cell lines (Table 1). Compound $\mathbf{1}$ was not cytotoxic against the glomerular basement membrane (GBM) noncancerous cell line, with an $\mathrm{IC}_{50}$ value higher than the maximum concentration tested $(343 \mu \mathrm{M})$. With $\mathrm{IC}_{50}$ values below 4 $\mu \mathrm{M}$ for HL-60 acute promyelocytic leukemia, HCT-8 human colon cancer, SF-295 human glioblastoma, ${ }^{[8]}$ and OVCAR-8 ovarian carcinoma, 1 can be considered selective for tumorigenic cells. Compound 2, lacking the ferrocenyl moiety, was likewise inactive against the GBM cell line. However, 2 was also inactive against HL-60, SF-295, and OVCAR-8 cell lines, with $\mathrm{IC}_{50}$ values above the maximum concentration tested $(25 \mu \mathrm{M})$ for all cell lines, showing that the Fc group is essential for antiproliferative effects. 


\section{Mechanistic studies in HL-60 cells}

To characterize the cytotoxic effect of $\mathbf{1}$, a phenotypic evaluation of treated HL-60 cells after $24 \mathrm{~h}$ incubation was performed. The tested concentrations were chosen as 1,2 , and $4 \mu \mathrm{M}$, based on $24 \mathrm{~h} \mathrm{IC}_{50}$ values. Negative control cells exhibited a typical non-adherent round morphology after $24 \mathrm{~h}$ in culture, while several 1-induced morphological changes typical of apoptosis, including a decrease in cell size and the formation of apoptotic bodies and intracellular vacuoles, were observed (Figure $1 \mathrm{~A}$ ). The severity of the effects increased with concentration, and at $4 \mu \mathrm{M}$, evidence of necrotic cell death was noted. The cytotoxic effects of compound 1 were confirmed by flow cytometry, demonstrating a concentration-dependent decrease in cell density (Figure 1 B). The mean number of cells decreased from $4.9 \times 10^{5}$ cells $\mathrm{mL}^{-1}$ in the negative control to $1.5 \times 10^{5}$ cells $\mathrm{mL}^{-1}$ under exposure to $\mathbf{1}$ at $4 \mu \mathrm{M}$; at this concentration, the effect was similar to that observed in the presence of the positive control doxorubicin at $0.5 \mu \mathrm{M}\left(1.4 \times 10^{5}\right.$ cells $\mathrm{mL}^{-1}$, Figure $\left.1 \mathrm{C}\right)$. The effect on cell density was accompanied by a decline in cell membrane integrity (Figure $1 \mathrm{C}$ ), although the effects on proliferation seemed to be more marked and likely related to more specific pathways than loss of membrane integrity. At the highest tested concentration, 1 decreased the cell number by $70 \%$, whereas cell membrane integrity was affected in only $25 \%$ of treated cells.

\begin{tabular}{|c|c|c|c|c|c|c|}
\hline \multirow[t]{2}{*}{ Compd } & \multicolumn{6}{|c|}{$\mathrm{IC}_{50}[\mu \mathrm{M}]^{[\mathrm{a}]}$} \\
\hline & HL-60 & HCT-8 & SF-295 & MDA-MB-435 & OVCAR-8 & GBM \\
\hline 1 & $1.040 \pm 04^{[8]}$ & $0.90 \pm 1^{[8]}$ & $1.00 \pm 2^{[8]}$ & $16 \pm 4^{[8]}$ & $3.4 \pm 0.6$ & \\
\hline 2 & $>25$ & ND & $>25$ & ND & $>25$ & $>343.0$ \\
\hline
\end{tabular}



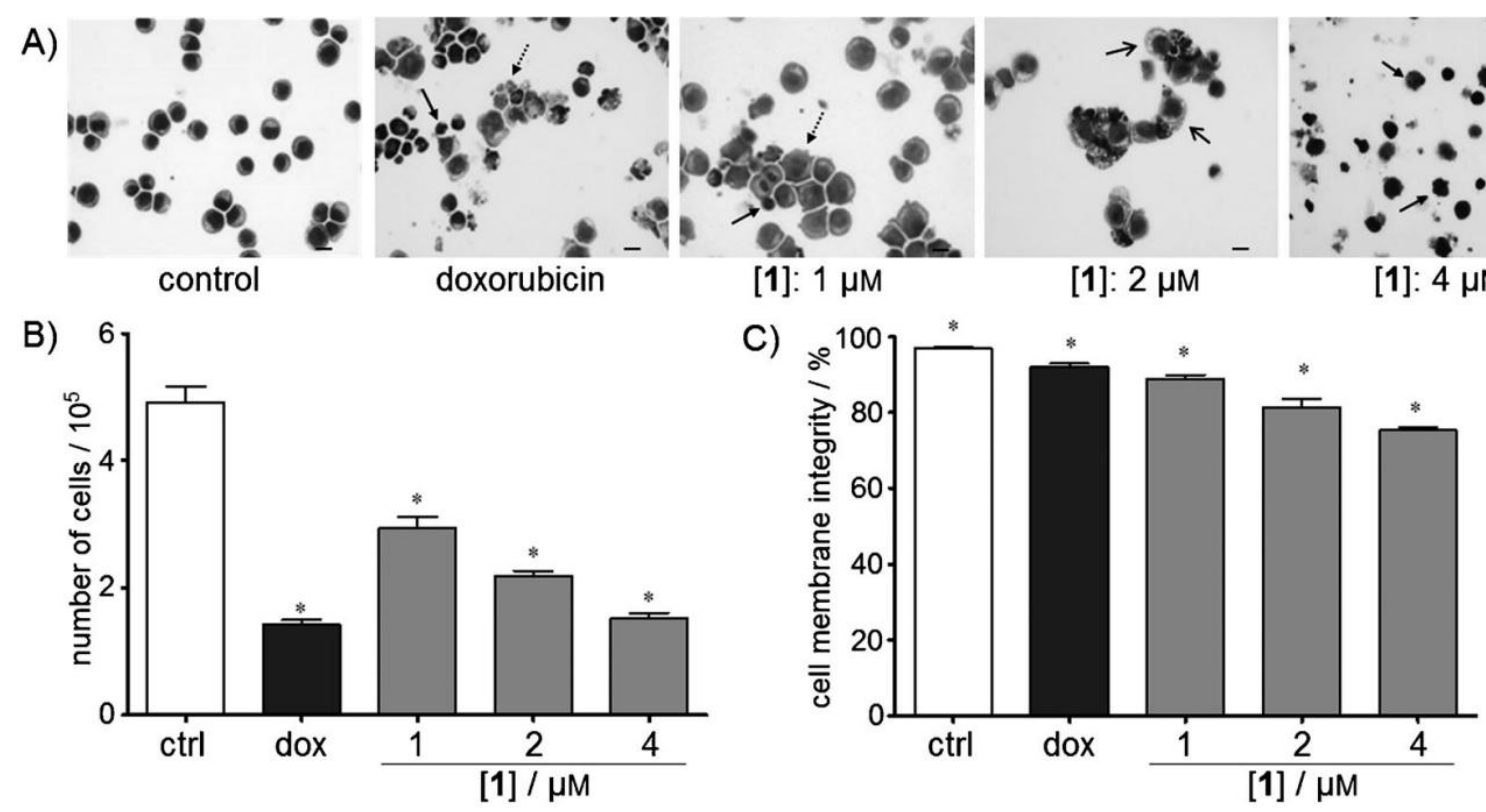

Figure 1. Effect of 1 on A) HL-60 cell morphology, B) membrane integrity, and C) cell number, as determined by application of hematoxylin/eosin $(\mathrm{H} / \mathrm{E})$ staining and flow cytometry. Data are presented as mean values \pm SEM of three independent experiments performed in triplicate; $* p<0.05$ relative to negative control by ANOVA, followed by Dunnett's test. HL-60 cells were treated with controls or $\mathbf{1}$ for $24 \mathrm{~h}$ at 1,2 , and $4 \mu \mathrm{M}$. DMSO $(0.2 \%)$ and $0.5 \mu \mathrm{M}$ doxorubicin were used as the negative and positive controls, respectively. For H/E staining in panel A), solid-head arrows denote necrotic cells, dashed arrows denote apoptotic bodies, and openhead arrows denote intracellular vacuoles. Scale bars: $20 \mu \mathrm{M}$.
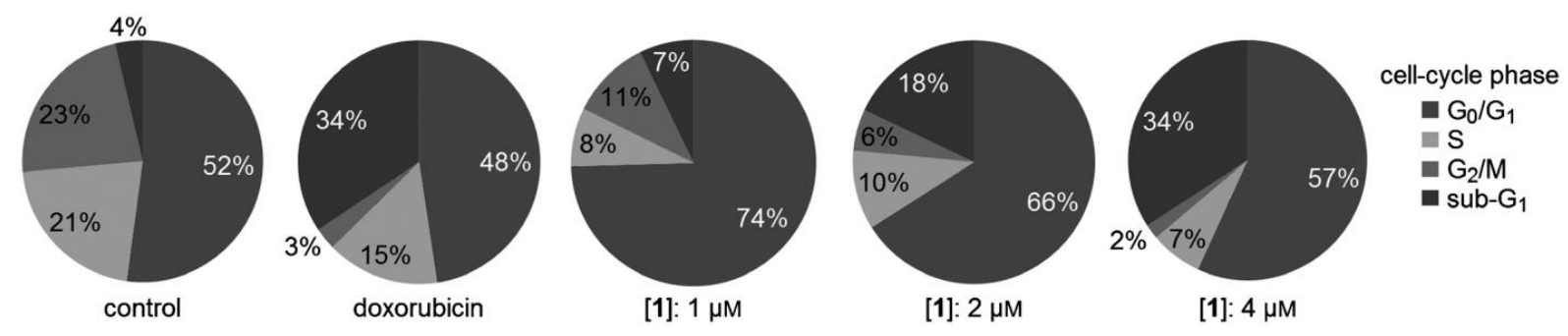

Figure 2. Effect of $\mathbf{1}$ on the cell-cycle distribution of HL-60 cells treated with controls or $\mathbf{1}$ for $24 \mathrm{~h}$ at 1,2 , and 4 $\mu \mathrm{M}$. Cell cycle was determined by flow cytometry, and pie graphs depict the percentage of cells in $G_{0} / G_{1}, S$, or $\mathrm{G}_{2} / \mathrm{M}$ phases; sub- $\mathrm{G}_{1}$ denotes fragmentation of DNA. DMSO $(0.2 \%)$ and $0.5 \mu \mathrm{M}$ doxorubicin were used as the respective negative and positive controls.

The cell-cycle distribution of HL-60 cells treated with 1 was analyzed by flow cytometry. Results demonstrated that cells were arrested at $\mathrm{G}_{0} / \mathrm{G}_{1}$, followed by a progressive increase in the number of cells with DNA fragmentation with increasing concentrations of compound (Figure 2). Cell-cycle arrest was most evident at $1 \mu \mathrm{M}$, with $74 \%$ of cells in $\mathrm{G}_{0} / \mathrm{G}_{1}$ compared 
with $52 \%$ in the negative control, while DNA fragmentation was maximum at the highest tested concentration $(4 \mu \mathrm{M})$, corresponding to $34 \%$, relative to $4 \%$ in the negative control.

DNA fragmentation is evidence for an increased number of dead cells, and is a signature of both necrotic and apoptotic processes. The externalization of PS, an important biomarker characteristic of the early stages of cell death by apoptosis, was observed in treated cells in a concentration-dependent manner. After $24 \mathrm{~h}$ of incubation, only 3\% of the negative control cells presented PS externalization, while in cells treated with 1 at $4 \mu \mathrm{M}$, this number increased to $38 \%$ (Figure $3 \mathrm{~A}$ ), suggesting that the effects of $\mathbf{1}$ are related to apoptosis induction. Apoptosis was also reinforced by the analysis of caspase 3 and 7 activation (Figure $3 \mathrm{~B}$ ). After $24 \mathrm{~h}$ of exposure to $4 \mu \mathrm{M}$ of $\mathbf{1}$, HL-60 cells presented an increase from 1.2 to $14 \%$ in caspase 3 and 7 activation, relative to the negative control.
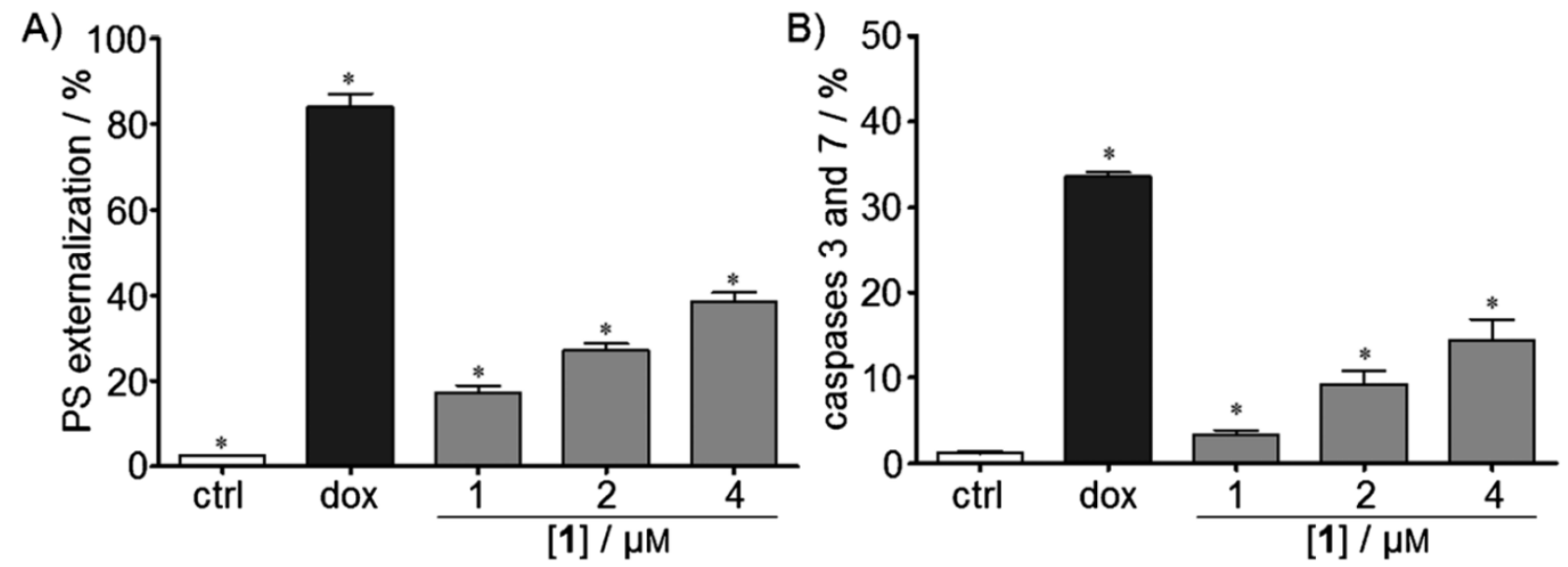

Figure 3. Effect of 1 on: A) phosphatidylserine externalization and B) activation of caspases 3 and 7 of HL-60 cells treated with controls or 1 for $24 \mathrm{~h}$ at 1,2 , and $4 \mu \mathrm{M}$. DMSO $(0.2 \%)$ and $0.5 \mu \mathrm{M}$ doxorubicin were used as the respective negative and positive controls. Cells were analyzed by flow cytometry, and data are presented as mean values SEM of two independent experiments performed in triplicate; ${ }^{*} \mathrm{p}<0.05$ relative to negative control by ANOVA, followed by Dunnett's test.

\section{DNA interaction}

Evaluation of the interaction of $\mathbf{1}$ with dsDNA-modified electrodes and with ssDNA in solution was carried out using electrochemical techniques. For dsDNA (Figure 4 A), the blank (grey line) showed no redox processes, as to be expected when the nucleoside bases are primarily paired. In the presence of $\mathbf{1}$ (black line), the appearance of diagnostic peaks corresponding to guanosine and adenosine oxidation represented a conformational change in 
the dsDNA, resulting from an interaction between 1 and dsDNA. Compound 1 could also interact with ssDNA (Figure $4 \mathrm{~B}$ ); here, the intensities of the adenosine and guanosine current peaks were diminished upon addition of $\mathbf{1}$ to the solution, without displacement in terms of peak potential. It is worth mentioning that the Fc moiety in $\mathbf{1}$ underwent oxidation in these experimental conditions, generating a positive charge on the molecule. This might cause an electrostatic attraction toward the phosphate backbone of DNA and could be a drawback in the use of electrochemical sensors for this system. Therefore, we investigated the possible interaction of $\mathrm{Fc}$ with dsDNA and ssDNA. Figure $4 \mathrm{C}$ shows the differential pulse voltammetry (DPV) scans of a solution containing ssDNA, with and without Fc. In this case, there was only a slight alteration in the oxidation currents of guanosine, suggesting negligible interaction with the ferricenium cation. Furthermore, no interaction of the ferricenium cation with dsDNA (Figure S1, Supporting Information) was observed, suggesting that the oxidation of the Fc moiety, per se, did not cause a false positive result.
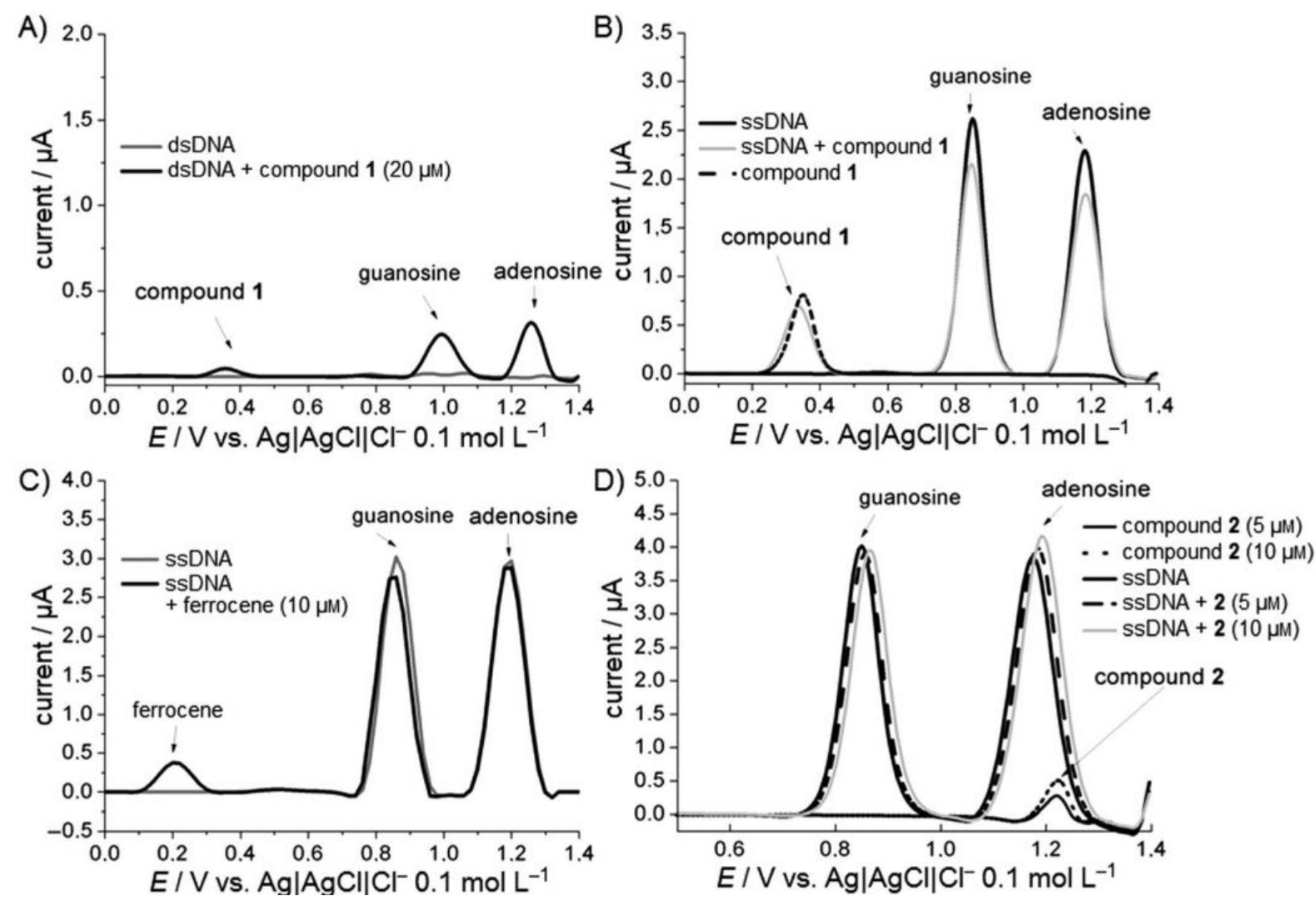

Figure 4. A) Differential pulse voltammetry at a dsDNA-modified GCE in acetate buffer+EtOH (4:1, pH 4.5), in the presence and absence of $\mathbf{1}(20 \mu \mathrm{M})$. B) Differential pulse voltammetry at a GCE in acetate buffer+EtOH (7:3, $\mathrm{pH} 4.5)$, and ssDNA in the presence and absence of $\mathbf{1}(10 \mu \mathrm{M})$. C) Differential pulse voltammetry at a GCE in acetate buffer+EtOH (7:3, pH 4.5), and ssDNA in the presence and absence of ferrocene $(10 \mu \mathrm{M})$. D) Differential pulse voltammetry at a GCE in acetate buffer+EtOH (7:3, pH 4.5), and ssDNA in the presence and absence of 2 (5 and $10 \mu \mathrm{M})$. 
Compound 2 did not interact with ssDNA, behavior that was confirmed by the lack of modification of the oxidation currents of guanosine and adenosine in ssDNA, similar to the behavior of Fc (Figure 4D). The result was ambiguous toward dsDNA, as the oxidation of compound $\mathbf{2}$ occurred at a similar potential to that of adenosine in dsDNA; however, the small difference in currents in both voltammograms suggests a slight interaction at most (Figure S2, Supporting Information).
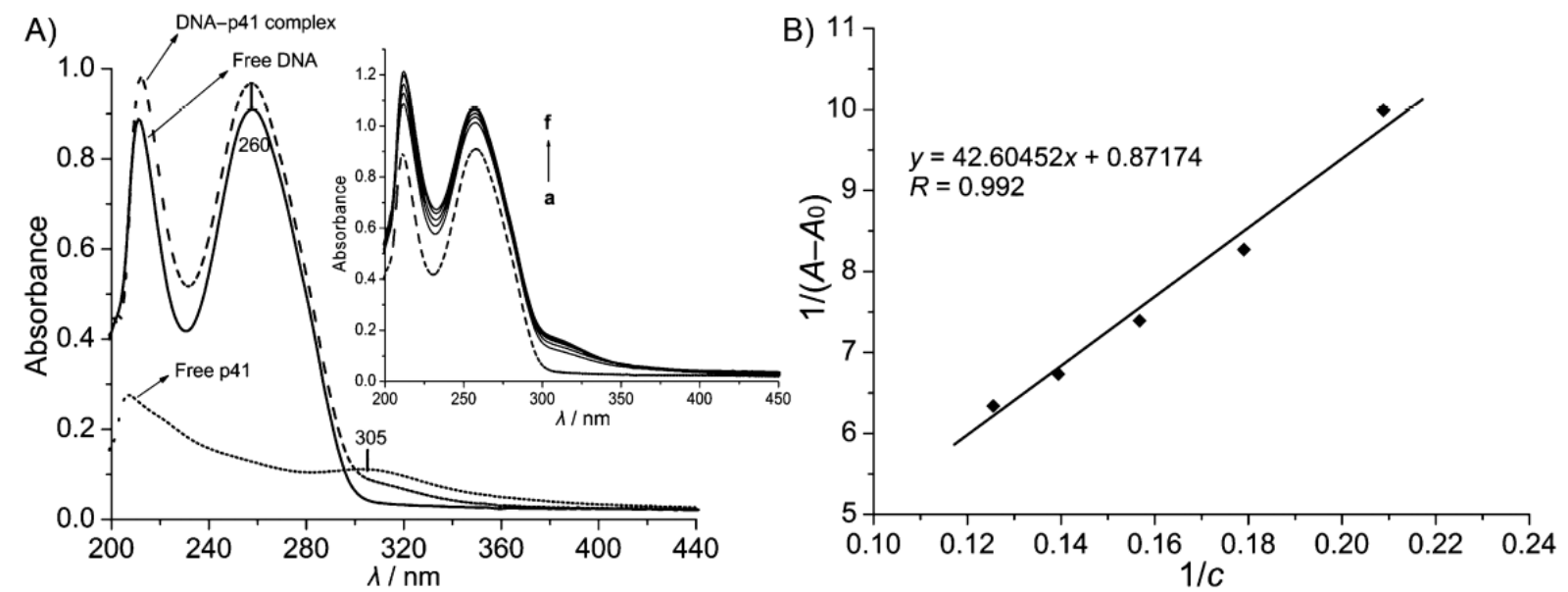

Figure 5. A) UV/Vis spectra for dsDNA $(130 \mu \mathrm{M})$, in the absence and presence of 1. Inset: The effect of the concentration of $1(3.2,4.0,4.8,5.6,6.4,7.2$, and $8 \mu \mathrm{M})$ on the spectral profile of dsDNA. B) Double reciprocal plot of 1 binding to DNA, where A0 is the initial absorption of free DNA and A is the absorption at various concentrations (c) of $\mathbf{1}$ at $260 \mathrm{~nm}$.

Spectrophotometric studies of the effects of compound $\mathbf{1}$ in calf thymus dsDNA were carried out to compare with the electrochemical investigation and to clarify the role of the preoxidation of Fc (Figure 5). In this experiment, a fixed concentration of DNA $(0.130 \mathrm{mM})$ in $30 \%$ ethanol/Tris solution was treated with different concentrations of 1 (3.2-8 mM). Figure 5A shows the spectra of the free dsDNA and of the complex formed by compound $\mathbf{1}$ and dsDNA. In order to display only the dsDNA-1 interaction, the spectrum of $\mathbf{1}$ was subtracted from the spectrum of the complex at the same concentration. An increase in the concentration of 1 provoked a hyperchromic effect on the dsDNA peak at $260 \mathrm{~nm}$ (Figure 5A). Hyperchromicity is typical of DNA interactions ${ }^{[9,10]}$ and has been attributed, for instance, to intercalation interactions with small molecules, which results in exposure of the base pairs to UV/Vis radiation and increasing absorbance. ${ }^{[9 c, 11,12]}$ The binding constant $(K)$ of the 1 -DNA complex was obtained by applying the Benesi-Hildebrand equation [Eq. (1)] to the band at 
$260 \mathrm{~nm}:{ }^{[9 \mathrm{c}]}$ in which $l$ is the path length $(1 \mathrm{~cm}), D_{\mathrm{t}}$ is the total DNA concentration, $\Delta \varepsilon_{\mathrm{DS}}$ is the molar absorptivity of the interaction complex, [S] is the analyte concentration, and $K_{\mathrm{DS}}$ is the stability constant for complex formation (DS). Thus, the ratio of the intercept to the slope in the double reciprocal plot in Figure $5 \mathrm{~B}$ gave the binding constant $\left(K_{\mathrm{DS}}\right) .^{[9 \mathrm{c}]}$ The binding constant for this interaction was found to be $2 \times 10^{4} \mathrm{M}^{-1}$, consistent with literature data for interaction of dsDNA with other intercalators, ${ }^{[9,13]}$ including ferrocenyl compounds. ${ }^{[9 a, 14]}$

$$
\frac{I}{\Delta A}=\frac{1}{D_{t} K_{D S} \Delta \varepsilon_{D S}[S]}+\frac{1}{D_{t} \Delta \varepsilon_{D S}}
$$

\section{Discussion}

The antitumor properties of the ferrocifens and derivatives have been well studied, particularly against ER+ (MCF-7) and ER- (MDA-MB-231) breast cancer cells. ${ }^{[6]}$ The antiproliferative activity of some of the most potent compounds has been attributed to formation of electrophilic intermediates and requires the presence of an oxidizable group conjugated to the ferrocenyl group. ${ }^{[6 f]}$ In this case, 1 possesses no such functional groups and was indeed less active on MDA-MB-231 cells $\left(\mathrm{IC}_{50}=7.54 \mu \mathrm{M}\right){ }^{[15]}$ than those compounds possessing phenol functionalities (e.g., $\mathrm{IC}_{50}=0.6 \mu \mathrm{M}$ for the $4,4^{\prime}$-dihydroxy analogue). ${ }^{[7]}$ Nonetheless, we felt that $\mathbf{1}$ merited further study, based on a recent discovery of its antiproliferative activity against SF295, HCT-8, and HL-60 tumor cells in the low micromolar range, the lack of unspecific toxicity on erythrocytes, and its lack of oxidative stress induction properties. $^{[8]}$

Compound 1 was selective toward tumor cells when compared with noncancerous cells; the mean $\mathrm{IC}_{50}$ value $(4.5 \mu \mathrm{M})$ against HL-60, HCT-8, SF-295, MDA-MB-435, ${ }^{[8]}$ and OVCAR-8 tumor cells compared favorably with that obtained using the noncancerous GBM monkey cell line $\left(\mathrm{IC}_{50}>343.00 \mu \mathrm{M}\right)$. Such selectivity toward tumor cells is a key factor in the development of new anticancer agents, with the goal of a decrease in side effects and an improvement in the quality of life of patients under chemotherapy. Often, such selectivity is suggestive of specific interactions with receptors present in cancer cells, such as the estrogen receptor (ER), which is targeted by hydroxytamoxifen. Although there is evidence of the presence of functional membrane ER $\alpha$ and ER $\beta$ in HL-60 leukemia cells, ${ }^{[16]}$ as well as functional ER $\beta$ for colon cancer cells, including HCT- $8,{ }^{[17]}$ analysis of the molecular data 
from the $\mathrm{NCI}^{[18]}$ showed that all cell lines used in the present work indeed express low levels of ERs relative to some breast (MCF-7 and T47D) and ovarian (SK-OV-3) overexpressing cells. Based on the present findings, the activity of $\mathbf{1}$ seems to be independent of an ER expression pattern.

Studies on the mechanism of action of $\mathbf{1}$ suggest that it induces cell-cycle arrest at the $\mathrm{G}_{0} / \mathrm{G}_{1}$ phase, followed by an increasing number of cells with DNA fragmentation. Usually, in the presence of DNA damage, cells can trigger a complex sequence of events, including checkpoint activation, leading to cell-cycle arrest, allowing DNA repair. Depending on the severity of the damage, cell death pathways can be activated. ${ }^{[19]}$ Indeed, cells treated with $\mathbf{1}$ underwent characteristic apoptotic cell death, as demonstrated by the morphology of the treated cells, the increasing number of cells with DNA fragmentation, and by PS externalization and caspase 3 activation, all phenotypic and biochemical features related to apoptosis. $^{[20]}$ It is useful to compare these results with what is already known about the biochemical mechanism of the ferrocifens. The effect on cell-cycle progression of the ferrocenyl analogue of hydroxytamoxifen (Fc-OH-TAM) depends on the ER expression pattern of treated cells; ${ }^{[21,6 e]}$ in ER+ cells, Fc-OH-TAM provokes arrest in the $G_{0} / G_{1}$ phase, while ER- cells are arrested in the $S$ phase. The authors furthermore linked the antiproliferative effects of Fc-OH-TAM with ROS production and senescence, which apparently is not the case for $\mathbf{1}$, as previous studies demonstrated that it was unable to elicit ROS production in HL-60 cells. ${ }^{[8]}$ This observation, as well as the observation that 1 provoked $G_{0} / G_{1}$ arrest, in spite of the low ER expression in HL-60 cells, suggest that the mechanisms of action for $\mathbf{1}$ and Fc-OH-TAM differ significantly.

Interestingly, Osella et al. ${ }^{[22]}$ showed that Fc-OH-TAM cytotoxicity cannot be directly attributed to oxidative stress, although it is known to provoke DNA damage. Indeed, one of the most important aspects in the discovery of antineoplastic agents is the interaction of these substances with DNA. Electrochemical experiments on 1 using a dsDNA biosensor or ssDNA in solution evidenced such an interaction. The obtained binding constant of $2 \times 10^{4} \mathrm{M}^{-1}$, as well as the hyperchromic effect upon addition of $\mathbf{1}$ to dsDNA, is consistent with weak intercalation between base pairs. ${ }^{[9 a, 11,12,23]}$ Studies to evaluate the interaction of Fc or the organic moiety 2 with dsDNA and ssDNA gave negative results, reinforcing the importance of the hybrid skeleton on the activity of $\mathbf{1} .^{[24]}$ 


\section{Conclusions}

2-Ferrocenyl-1,1-diphenylbut-1-ene (1) was not cytotoxic toward GBM monkey cells but was able to decrease, in a concentration-dependent manner, the number of viable cells in the HL60 line. Cell death was caused by apoptosis, as evidenced by morphological analyses, activation of effector caspases 3 and 7, increased DNA fragmentation, externalization of PS, and a necrosis process at the highest concentration. Furthermore, $\mathbf{1}$ interfered with the cell cycle, leading to accumulation of cells in the $G_{0} / G_{1}$ phase. Interaction with dsDNA and ssDNA suggests that the mechanism of action involves molecular damage to DNA via intercalation.

\section{Experimental Section}

\section{Preparation of 2-ferrocenyl-1,1-diphenylbut-1-ene (1) and 1,1,2-triphenylbut-1-ene (2)}

The synthesis of $\mathbf{1}$ has been previously reported. ${ }^{[7]}$ Briefly, $\mathbf{1}$ was obtained by a Friedel-Crafts acylation of Fc, followed by a McMurry cross-coupling of propionyl Fc with benzophenone.

The preparation and characterization of 2 has been reported. ${ }^{[25]}$ However, we here used a onestep McMurry method, starting from commercially available propiophenone and benzophenone. Titanium chloride $(7.6 \mathrm{~g}, 4.4 \mathrm{~mL}, 40 \mathrm{mmol})$ was added dropwise to a suspension of zinc powder $(3.9 \mathrm{~g}, 60 \mathrm{mmol})$ in dry $\mathrm{THF}$ at $10^{\circ} \mathrm{C}$. The mixture was heated at reflux for $2 \mathrm{~h}$. A second solution was prepared by dissolving propiophenone $(1.34 \mathrm{~g}, 1.33 \mathrm{~mL}$, $10 \mathrm{mmol})$ and benzophenone $(1.82 \mathrm{~g}, 10 \mathrm{mmol})$ in dry THF. This latter solution was added dropwise to the first solution, and the solution was stirred at reflux for an additional $2 \mathrm{~h}$. After cooling to room temperature, the mixture was stirred with water and dichloromethane, acidified with dilute hydrochloric acid until the dark color disappeared, and decanted. The aqueous layer was extracted with dichloromethane, and the organic layers were combined and dried over magnesium sulfate. After concentration under reduced pressure, the crude product was separated by preparative HPLC with acetonitrile as the eluent to yield pure 2 in 55\% yield. Physicochemical data were identical to those in the literature. ${ }^{[25]}$

Compounds $\mathbf{1}$ and $\mathbf{2}$ were purified by semi-preparative HPLC before use. Elemental analysis of $\mathbf{1}$ and ${ }^{13} \mathrm{C}$ NMR of 2 confirmed $>95 \%$ purity. 


\section{Biochemistry}

Cell lines: HL-60 (acute promyelocytic leukemia), OVCAR-8 (ovarian carcinoma), and SF295 (glioblastoma) cell lines were provided by the U.S. National Cancer Institute (Bethesda, $\mathrm{MD})$. Glomerular basement membrane (GBM) monkey cells were used as a noncancerous cell line for comparison. Cells were maintained in RPMI 1640 medium supplemented with 10\% fetal bovine serum and $1 \%$ antibiotics at $37^{\circ} \mathrm{C}$ in a humidified atmosphere of $5 \% \mathrm{CO}_{2}$ and $95 \%$ air.

Cytotoxicity: Cytotoxicity was determined using the MTT (3-(4,5-dimethylthiazol-2-yl)-2,5diphenyltetrazolium bromide) assay. ${ }^{[26]}$ Accordingly, GBM, HL-60, OVCAR-8, and SF-295 cell lines were seeded in 96-well plates and incubated with $1(0.02-343 \mu \mathrm{M})$ or vehicle control (DMSO, $0.5 \%)$ for $72 \mathrm{~h}$. After the incubation period, a solution of MTT (1 $\mu \mathrm{M})$ was added to each well and incubated for $3 \mathrm{~h}$. Plates were spectrophotometrically evaluated at 570 $\mathrm{nm}$, and $\mathrm{IC}_{50}$ values were determined using the GraphPad Prism 5.0 software.

Mechanistic studies: For the following experiments, HL-60 cells were seeded at a density of 3 x $10^{5}$ cells $\mathrm{mL}^{-1}$ and incubated with 1,2 , or $4 \mu \mathrm{M}$ of $\mathbf{1}$ for $24 \mathrm{~h}$. The vehicle (DMSO, $0.5 \%$ ) and doxorubicin $(0.5 \mu \mathrm{M})$ were used as negative and positive controls, respectively. Statistical analyses of results were performed using the GraphPad Prism 5.0 software.

Analysis of morphological changes-(H/E stain): Untreated or 1-treated cells were examined for morphological changes by light microscopy (Olympus, Tokyo, Japan). To evaluate nuclear morphology, cells were harvested, transferred to cytospin slides, fixed with methanol for $1 \mathrm{~min}$, and stained with hematoxylin and eosin.

Flow cytometry analysis: All experimental procedures adopted in flow cytometry analyses essentially followed the methodology described by Montenegro et al. ${ }^{[27]}$ The evaluated parameters were cell membrane integrity, DNA fragmentation, cell cycle, PS externalization and caspase 3/7 activation. For all experiments, 5000 events were evaluated using a Guava EasyCyte Mine flow cytometer and Guava Express Plus software. DNA fragmentation and the cell cycle were analyzed by ModFit LT for Win32 version 3.1.

\section{DNA interaction studies}

Electrochemistry with dsDNA biosensors: The ability of $\mathbf{1}$ and $\mathbf{2}$ to interact dsDNA was investigated using an electrochemical approach employing DNA-modified glassy carbon 
electrode (GCE) biosensors. ${ }^{[28,29]}$ The electrochemical experiments were performed with a conventional undivided three electrode cell using an Autolab PGSTAT-30 potentiostat (Echo Chemie, Utrecht, the Netherlands) coupled to a microcomputer, interfaced by GPES 4.9 software. A working GCE (diameter=3 mm), a Pt wire counter electrode, and a $\mathrm{Ag} \mid \mathrm{AgCl}, \mathrm{Cl}^{-}$ (saturated) reference electrode were used. All experiments were conducted at room temperature $\left(25 \pm 2{ }^{\circ} \mathrm{C}\right)$ after purging with argon. The DNA used was type I calf thymus (Sigma Aldrich, Saint Louis, USA), highly polymerized, containing 6.2\% $\mathrm{Na}$ and $13 \% \mathrm{H}_{2} \mathrm{O}$, dried, and stored at $8{ }^{\circ} \mathrm{C}$. The electrochemical procedure for the investigation of dsDNA interaction with compounds $\mathbf{1}$ and $\mathbf{2}$ involved three steps: preparation of the GCE surface, immobilization of dsDNA gel, and voltammetric transduction. Initially, the GCE was polished with alumina (BAS polishing kit). The electrode was then electrochemically pre-treated with a sequence of 5 cyclic potential scans from 0 to $+1.4 \mathrm{~V}$ versus $\mathrm{Ag} \mid \mathrm{AgCl}, \mathrm{KCl}(0.1 \mathrm{M})$ in acetate buffer, washed thoroughly with distilled/deionized water, and dried. In order to immobilize the dsDNA, the surface of the electrode was coated with $10 \mathrm{~mL}$ of calf thymus DNA solution (containing $12.0 \mathrm{mg}$ of dsDNA in $1.0 \mathrm{~mL}$ of acetate buffer, $\mathrm{pH} 4.5$, stored at $20^{\circ} \mathrm{C}$ for $48 \mathrm{~h}$ ), the gel was allowed to dry at room temperature under a stream of nitrogen, and the biosensor was subsequently immersed in $5 \mathrm{~mL}$ of aqueous-ethanolic (30\%) acetate buffer, $\mathrm{pH} 4.5$. For each series of experiments, an identical dsDNA-GCE was prepared as a reference blank. Before analysis, the modified electrode was left for $10 \mathrm{~min}$ in contact with the buffer solution containing either $20 \mathrm{~mL}$ of ethanol (negative control), Fc $(10 \mu \mathrm{M}), \mathbf{1}(20 \mu \mathrm{M})$, or $2(10 \mu \mathrm{M})$. DPV scans $\left(v=10 \mathrm{mV} \mathrm{s}^{-1}\right.$, pulse amplitude=50 mV and pulse width=70 ms $)$ and baseline corrections were performed using GPES 4.9. ${ }^{[28,29]}$

Electrochemistry of ssDNA in solution: To produce ssDNA by acid-base treatment, dsDNA (1 $\mathrm{mg})$ was dissolved in $1 \mathrm{M} \mathrm{HCl}(100 \mathrm{~mL})$ by heating at $100^{\circ} \mathrm{C}$ in a sealed glass tube immersed in a boiling water bath for $1 \mathrm{~h}$, followed by neutralization with $1 \mathrm{M} \mathrm{NaOH}^{[29,30]} \mathrm{A}$ freshly prepared solution, consisting of $4 \mathrm{~mL}$ ssDNA and $950 \mathrm{~mL}$ of ethanol, ${ }^{[28-30]}$ was added to the electrochemical cell. Single-scan DPV experiments were conducted between 0 and $+1.4 \mathrm{~V}$ versus $\mathrm{Ag} \mid \mathrm{AgCl}, \mathrm{KCl}(0.1 \mathrm{M}),\left(v=10 \mathrm{mV} \mathrm{s}^{-1}\right.$, pulse amplitude $=50 \mathrm{mV}$ and pulse width=70 $\mathrm{ms})$. Peaks corresponding to the oxidation of guanine and adenine appeared at $+0.815 \mathrm{~V}$ and $+1.164 \mathrm{~V}$, respectively. After rinsing the surface, the GCE was inserted into a solution containing 1 or $2(50 \mathrm{~mL}$, corresponding to a concentration of $10 \mu \mathrm{M})$ or Fc $(10 \mu \mathrm{M})$, and the DPV experiment was repeated. A clean GCE was also employed in DPV experiments involving a $0.1 \mathrm{mM}$ buffered solution of 1 alone $(\mathrm{pH} 4.5)$, in order to observe possible 
interference of oxidation waves from compounds $\mathbf{1}$ or $\mathbf{2}$. Baseline corrections were made using the software GPES 4.9.

Spectrophotometric evaluation of interaction with dsDNA: Spectrophotometric studies were carried out with a Shimadzu Multispec 1501 or diode array Hewlett Packard 8453 spectrophotometer. The interaction of compound $\mathbf{1}$ with dsDNA was monitored by the absorption titration method, ${ }^{[9,10]}$ in which a fixed concentration of DNA $(130 \mu \mathrm{M})$ was treated with different concentrations of compound 1 (3.2-8 $\mu \mathrm{M})$ in Tris- $\mathrm{HCl}$ buffer $(\mathrm{pH} 7.4,0.1 \mathrm{M}$, $30 \%$ ethanol). A stock solution of DNA was prepared by dissolving $12 \mathrm{mg}$ of calf thymus DNA per $\mathrm{mL}$ of acetate buffer. An aliquot $(10 \mathrm{~mL})$ was then dissolved in Tris-HCl buffer and kept at $8{ }^{\circ} \mathrm{C}$ for $24 \mathrm{~h}$, stirring at frequent intervals to ensure the homogeneity of the solution. The final concentration of the dsDNA solution was measured spectrophotometrically at 260 $\mathrm{nm}$, using the molar extinction coefficient of $\varepsilon_{260}=6600 \mathrm{~cm}^{-1} \mathrm{M}^{-1}$ per nucleotide for calf thymus DNA. ${ }^{[9 a, d]}$ The concentration of the DNA solution was adjusted to $130 \mu \mathrm{M}$. The ratio between the absorbance values at 260 and $280 \mathrm{~nm}$ in the DNA spectra (A260/A280) was measured as 1.81, indicative of DNA free of protein contamination. ${ }^{[9 a, 31]}$ The same procedure was performed for compound 2.

\section{Acknowledgements}

This research was supported by grants from the Conselho Nacional de Desenvolvimento Científico e Tecnológico (CNPq), CAPES, CAPES/PNPD, RENORBIO, UFAL, and the National Cancer Institute of Brazil. The authors are also indebted to PRONEX-CNPqFAPEAL and the CNRS.

[1] a) "Ferrocene-functionalized endocrine modulators as anticancer agents": E. A. Hillard, A. Vessières, G. Jaouen in TopOrgan, Vol. 32, Springer, Berlin/Heidelberg, 2010, pp. 81 - 117; b) G. Gasser, I. Ott, N. Metzler-Nolte, J. Med. Chem. 2011, 54, 3 - 25; c) S. S. Braga, A. M. S. Silva, Organometallics 2013, 32, 5626 - 5639; d) D. Plazuk, J. Zakrzewski, M. Salmain, A. Blauz, B. Rychlik, P. Strzelczyk, A. Bujacz, G. Bujacz, Organometallics 2013, 32, 5774 - 5783.

[2] a) F. Dubar, C. Slomianny, J. Khalife, D. Dive, H. Kalamou, Y. Guérardel, P. Grellier, C. Biot, Angew. Chem. Int. Ed. 2013, 52, 7690 - 7693; Angew. Chem. 2013, 125, 7844 
- 7847; b) A. Mahajan, L. Kremer, S. Louw, Y. Guérardel, K. Chibale, C. Biot, Bioorg. Med. Chem. Lett. 2011, 21, 2866 - 2868; c) K. Kumar, S. Carrere-Kremer, L. Kremer, Y. Guerardel, C. Biot, V. Kumar, Organometallics 2013, 32, 5713 - 5719.

[3] a) K. Kowalski, J. Skiba, L. Oehninger, I. Ott, J. Solecka, A. Rajnisz, B. Therrien, Organometallics 2013, 32, 5766 - 5773; b) B. Maity, M. Roy, S. Saha, A. R. Chakravarty, Organometallics 2009, 28, 1495 - 1505; c) D. R. van Staveren, N. Metzler-Nolte, Chem. Rev. 2004, 104, 5931 - 5986.

[4] a) P. Köpf-Maier, H. Köpf, E. W. Neuse, Angew. Chem. Int. Ed. Engl. 1984, 23, 456 457; Angew. Chem. 1984, 96, 446 - 447; b) P. Köpf-Maier, H. Köpf, E. W. Neuse, J. Cancer Res. Clin. Oncol. 1984, 108, 336 - 340.

[5] a) J. Spencer, A. P. Mendham, A. K. Kotha, S. C. W. Richardson, E. A. Hillard, G. Jaouen, L. Male, M. B. Hursthouse, Dalton Trans. 2009, 918 - 921; b) S. Top, J. Tang, A. Vessières, D. Carrez, C. Provot, G. Jaouen, Chem. Commun. 1996, 8, 955 - 956; c) J. J. Cázares-Marinero, S. Top, A. Vessières, G. Jaouen, Dalton Trans. 2014, 43, 817 830.

[6] a) S. Top, A. Vessières, G. Leclercq, J. Quivy, J. Tang, J. Vaissermann, M. Huché, G. Jaouen, Chem. Eur. J. 2003, 9, 5223 - 5236; b) E. A. Hillard, A. Vessières, S. Top, P. Pigeon, K. Kowalski, M. Huché, G. Jaouen, J. Organomet. Chem. 2007, 692, 1315 1326; c) A. Vessières, S. Top, P. Pigeon, E. A. Hillard, L. Boubeker, D. Spera, G. Jaouen, J. Med. Chem. 2005, 48, 3937 - 3940; d) P. Pigeon, S. Top, O. Zekri, E. A. Hillard, A. Vessières, M. A. Plamont, O. Buriez, E. Labbé, M. Huché, S. Boutamine, C. Amatore, G. Jaouen, J. Organomet. Chem. 2009, 694, 895 - 901; e) A. L. Lainé, E. Adriaenssens, A. Vessières, G. Jaouen, C. Corbet, E. Desruelles, P. Pigeon, R. A. Toillon, C. Passirani, Biomaterials 2013, 34, 6949 - 6956; f) E. Hillard, A. Vessières, L. Thouin, G. Jaouen, C. Amatore, Angew. Chem. Int. Ed. 2006, 45, 285 - 290; Angew. Chem. 2006, 118, $291-296$.

[7] E. A. Hillard, P. Pigeon, A. Vessières, C. Amatore, G. Jaouen, Dalton Trans. 2007, $5073-5081$.

[8] A. C. de Oliveira, E. A. Hillard, P. Pigeon, D. D. Rocha, F. A. R. Rodrigues, R. C. Montenegro, L. V. Costa-Lotufo, M. O. F. Goulart, G. Jaouen, Eur. J. Med. Chem. 2011, $46,3778-3787$. 
[9] a) A. Shah, R. Qureshi, A. M. Khan, R. A. Khera, F. L. Ansari, J. Braz. Chem. Soc. 2010, 21, 447 - 451; b) N. K. Janjua, A. Shaheen, A. Yaqub, F. Perveen, S. Sabahat, M. Mumtaza, C. Jacob, L. A. Ba, H. A. Mohammed, Spectrochim. Acta Part A 2011, 79, 1600 - 1604; c) S. Agarwal, D. K. Jangir, R. Mehrotra, J. Photochem. Photobiol. B 2013, 120, 177 - 182; d) H. R. Mahler, B. Kline, B. P. Mehrotra, J. Mol. Biol. 1964, 9 , $801-811$.

[10] R. Vijayalakshmi, M. Kanthimathi, V. Subramanian, B. U. Nair, Biochem. Biophys. Res. Commun. 2000, 271, $731-734$.

[11] R. Hajian, T. G. Huat, J. Spectrosc. 2013, DOI: 10.1155/2013/380352.

[12] A. H. Hegde, S. N. Prashanth, J. Seetharamappa, J. Pharm. Biomed. Anal. 2012, 63, 40 $-46$.

[13] A. Rescifina, C. Zagni, M. G. Varrica, V. Pistarà, A. Corsaro, Eur. J. Med. Chem. 2014, $74,95-115$.

[14] F. Asghar, A. Badshah, A. Shah, M. K. Rauf, M. I. Ali, M. N. Tahirb, E. Nosheen, Ziaur-Rehman, R. Qureshi, J. Organomet. Chem. 2012, 717, 1 - 8.

[15] M. Gormen, P. Pigeon, S. Top, E. A. Hillard, M. Huché, C. G. Hartinger, F. de Montigny, M.-A. Plamont, A. Vessières, G. Jaouen, ChemMedChem 2010, 5, 2039 2050 .

[16] M. A. Kauss, G. Reiterer, R. P. Bunaiciu, A. Yen, Exp. Cell Res. 2008, 314, 2999 3006.

[17] G. Fiorelli, L. Picariello, V. Martineti, F. Tonelli, M. L. Brandi, Biochem. Biophys. Res. Commun. 1999, 261, $521-527$.

[18] Molecular Target Data, NCI Wiki, U.S. National Cancer Institute, https:// wiki.nci.nih.gov/display/NCIDTPdata/Molecular+Target+Data (accessed July 2014).

[19] a) H. Okada, T. W. Mak, Nat. Rev. Cancer 2004, 4, 592 - 603; b) H. Rodriguez-Rocha, A. Garcia-Garcia, M. I. Panayiotidis, R. Franco, Mutat. Res. 2011, 711, 158 - 166.

[20] a) K. Nishida, O. Yamaguchi, K. Otsu, Circ. Res. 2008, 103, 343 - 351; b) S. J. Martin, D. R. Green, Cell 1995, 82, $349-352$. 
[21] A. Vessières, C. Corbet, J. M. Heldt, N. Lories, N. Jouy, I. Laios, G. Leclercq, G. Jaouen, R. A. Toillon, J. Inorg. Biochem. 2010, 104, 503 - 511.

[22] D. Osella, H. Mahboobi, D. Colangelo, G. Cavigiolio, A. Vessières, G. Jaouen, Inorg. Chim. Acta 2005, 358, 1993 - 1998.

[23] U. Pindur, M. Jansen, T. Lemster, Curr. Med. Chem. 2005, 12, 2805 - 2847.

[24] E. H. Kerns, L. Di, Drug-like Properties: Concepts, Structure, Design and Methods, Academic Press, London, 2008.

[25] M. R. Schneider, E. von Angerer, H. Schonenberger, R. T. Michel, H. P. Fortmeyer, J. Med. Chem. 1982, 25, $1070-1077$.

[26] T. Mosmann, J. Immunol. Methods 1983, 65, 55 - 63.

[27] R. C. Montenegro, A. J. Araújo, M. T. Molina, J. D. B. Marinho-Filho, D. D. Rocha, E. Lopez-Montero, M. O. F. Goulart, E. S. Bento, A. P. N. N. Alves, C. Pessoa, M. O. Moraes, L. V. Costa-Lotufo, Chem. Biol. Interact. 2010, 184, 439 - 448.

[28] A. J. Araújo, A. A. de Souza, E. N. da Silva Júnior, J. D. B. Marinho-Filho, M. A. B. F. de Moura, D. D. Rocha, M. C. Vasconcellos, C. O. Costa, C. Pessoa, M. O. de Moraes, V. F. Ferreira, F. C. Abreu, A. V. Pinto, R. C. Montenegro, L. V. Costa-Lotufo, M. O. F. Goulart, Toxicol. In Vitro 2012, 26, 585 - 594.

[29] F. C. de Abreu, F. S. de Paula, D. C. M. Ferreira, V. B. Nascimento, J. C. D. Lopes, A. M. C. Santos, M. M. Santoro, C. E. Salas, M. O. F. Goulart, Sensors 2008, 8, 1519 1538 .

[30] C. O. L. Costa, E. O. C. Costa, F. R. Ferreira, L. S. Viana, F. A. S. Silva, F. C. Abreu, I. M. Figueiredo, Jr., W. Pinho, E. S. Bento, T. L. G. Lemos, O. D. L. Pessoa, B. Aguilera-Venegas, E. Norambuena, C. Olea-Azar, M. O. F. Goulart, J. Braz. Chem. Soc. 2012, 23, $1174-1185$.

[31] N. K. Janjuaa, A. Siddiqa, A. Yaqub, S. Sabahat, R. Qureshi, S. Ul Haque, Spectrochim. Acta Part A 2009, 74, 1135 - 1137. 


\section{Supporting Information}

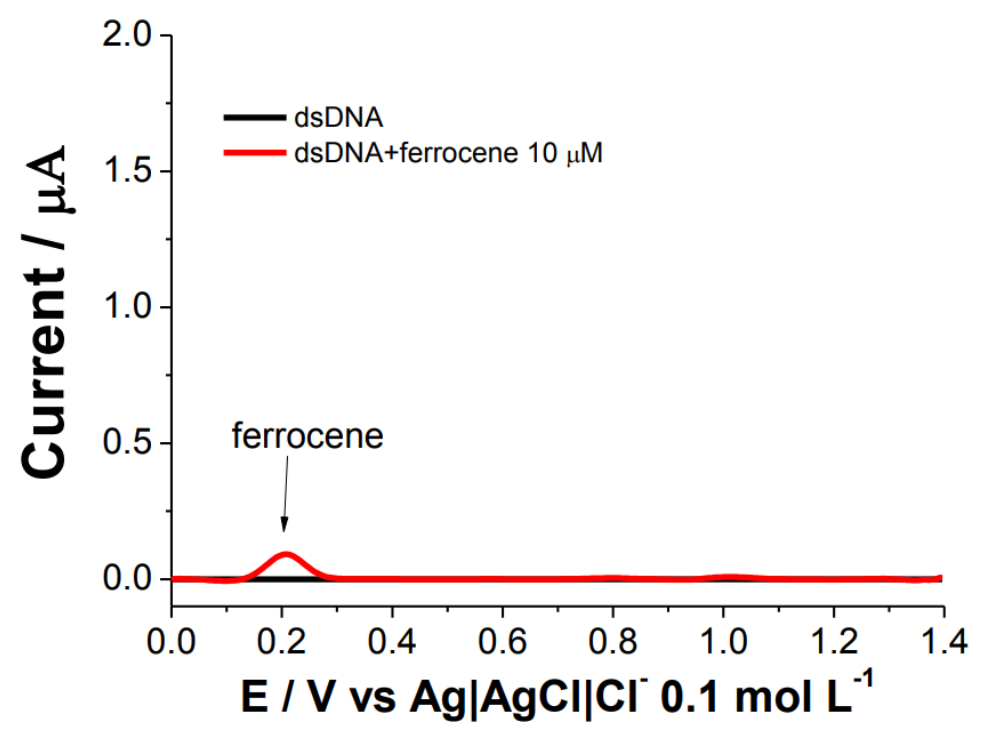

Figure SI1. (A) Differential pulse voltammetry at a dsDNA-modified glassy carbon electrode (GCE) in acetate buffer + $\mathrm{EtOH}(4: 1, \mathrm{pH} 4.5)$, with or without the addition of ferrocene $(10 \mu \mathrm{M})$. Here, the blank showed small peaks for guanosine and adenosine, suggesting that the bases were not completely paired. Thus, the blank was subtracted from both DPVs for visual clarity.

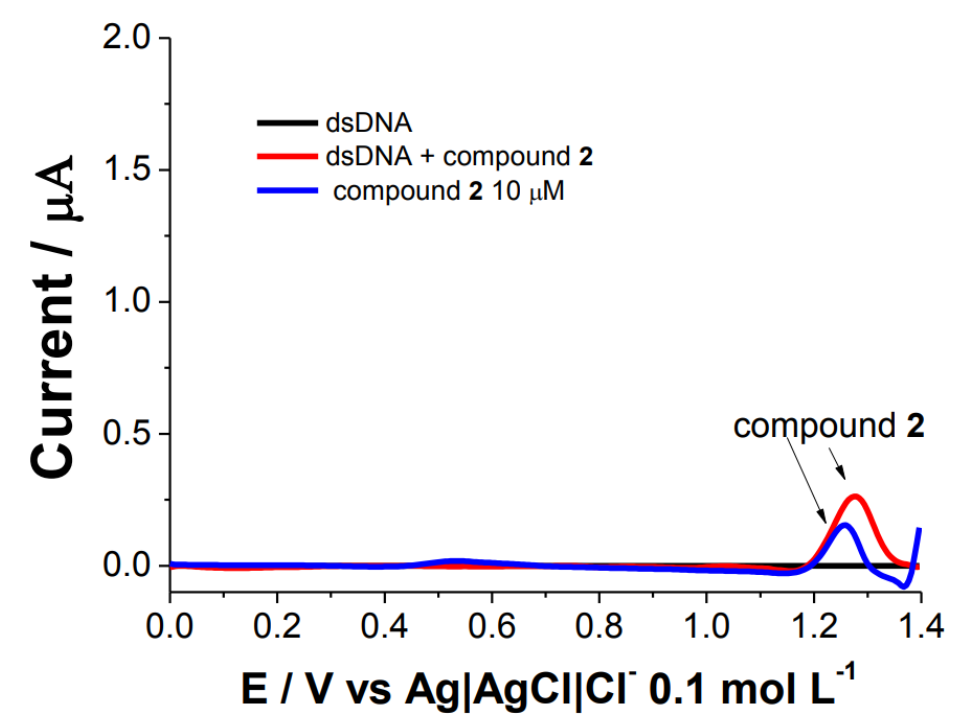

Figure SI2. (A) Differential pulse voltammetry at a dsDNA-modified glassy carbon electrode (GCE) in acetate buffer + $\mathrm{EtOH}(4: 1, \mathrm{pH} 4.5)$, without (black line) or with (red line) the addition of compound 2 $(10 \mu \mathrm{M})$; (blue line) represents the $\mathrm{CV}$ of compound $\mathbf{2}$ alone $(10 \mu \mathrm{M})$. Here, the blank showed small peaks for guanosine and adenosine, suggesting that the bases were not completely paired. Thus, the blank was subtracted from both DPVs for visual clarity. 